\title{
FEASIBILITY OF EARLY Pinus taeda L. SELECTION TO ASSESS GROWTH VARIABLES IN PROGENY TEST
}

\author{
Paulo Cesar Flôres Júnior ${ }^{*}$, Vanessa Ishibashi², Jorge Luis Monteiro de Matos ${ }^{3}$, Diego Tyska Martinez ${ }^{4}$, \\ Antonio Rioyei Higa ${ }^{5}$ \\ 1*Universidade Federal Rural da Amazônia, Instituto de Ciências Agrárias, Belém, Pará, Brasil - paulocesarfloresjunior@ gmail.com \\ ${ }^{2}$ Universidade Federal do Paraná, Programa de Pós-Gradução em Engenharia Florestal, Curitiba, Paraná, Brasil - \\ vanessa.ishibashi@gmail.com \\ ${ }^{3}$ Universidade Federal do Paraná, Programa de Pós-Gradução em Engenharia Florestal, Curitiba, Paraná, Brasil - jmatos.ufpr@gmail.com \\ ${ }^{3}$ Universidade Federal do Paraná, Programa de Pós-Gradução em Engenharia Florestal, Curitiba, Paraná, Brasil - diegotyska@ @otmail.com \\ ${ }^{3}$ Universidade Federal do Paraná, Programa de Pós-Gradução em Engenharia Florestal, Curitiba, Paraná, Brasil - higa@ ufpr.br
}

Received for publication: 10/06/2020 - Accepted for publication: 19/03/2021

\begin{abstract}
Resumo
Viabilidade de seleção precoce de Pinus taeda para variáveis de crescimento em teste de progênies. Programas de melhoramento genético de espécies florestais demandam um grande período até que as plantas atinjam idade adequada de seleção de genótipos superiores, sendo esse um fator crítico no processo seletivo. Assim, objetivou-se estimar parâmetros genéticos em idade juvenil e adulta (seis, 10 e 20 anos), visando verificar a correlação genética entre as variáveis nas diferentes idades e nas idades; e determinar se na idade juvenil é possível realizar a seleção precoce com eficiência. O teste foi implantado em 1997 com 120 progênies em delineamento de blocos casualizados, com cinco repetições, parcelas lineares de cinco plantas e espaçamento 2,5 m x 2,5 m. Aos seis, 10 e 20 anos foi realizada mensuração do DAP $(\mathrm{cm})$, ALT $(\mathrm{m})$ e VOL $\left(\mathrm{m}^{3}\right)$ de todos os indivíduos do teste. As estimativas de componentes de variância, parâmetros genéticos, correlação genética entre variáveis e entre idades foram efetuados utilizando o software Selegen REML/BLUP®. As estimativas dos parâmetros genéticos demonstraram superioridade aos 10 anos, em relação aos seis e 20 anos. A variável DAP demonstrou alta correlação genética com altura (ALT) e volume (VOL), sendo que a correlação genética entre DAP x VOL demonstrou-se de alta magnitude $(0,98)$ aos 10 anos de idade. A correlação genética entre idades, demonstrou que aos 10 anos, temos correlações de média magnitude com seis e 20 anos. A seleção precoce é indicada para 10 anos, para ciclos de 20 anos, sendo que nesta idade temos maior eficiência de seleção para a predição de ganhos em relação à idade adulta.

Palavras-chave: parâmetros genéticos. REML/BLUP. idade juvenil. seleção individual.
\end{abstract}

Abstract
Forest species breeding programs require a long period-of-time for plants to reach the proper age to enable
selecting superior genotypes, which is a critical factor in selection processes. Thus, the aims of the current study
are to estimate genetic parameters in juvenile and adult plants ( 6,10 and 20 years) in order to investigate genetic
correlations between variables at different ages and at certain ages; as well as to determine whether it is possible
performing efficient early selection in juvenile plants. The test was implemented in 1997; it comprised 120
progenies and followed a randomized block design, with five repetitions - linear plots comprised 5 plants at 2.5
m x 2.5 m spacing. DBH $(\mathrm{cm}), \mathrm{H}(\mathrm{m})$ and VOL $\left(\mathrm{m}^{3}\right)$ of all tested subjects were measured at the age of 6,10
and 20 years. Variance components, genetic parameters, as well as genetic correlations between variables and
between ages were estimated in Selegen REML/BLUPß software. Genetic parameter estimates have shown
superiority at 10 years, in comparison to that estimated at 6 and 20 years. Variable 'DBH' has shown high
genetic correlation to height (H) and volume (VOL), whereas DBH x VOL have shown high genetic correlation
(0.98) in 10 -year-old plants. With respect to genetic correlation between ages, 10 -year-old plants have shown
moderate correlation to 6- and 20 -year-old plants. Early selection is indicated for 10 -year-old plants, in 20 -year
cycles, since plants at this age have shown higher selection efficiency to predict gains in comparison to adult
plants.
Keywords: genetic parameters. REML/BLUP. juvenile age. individual selection.

\section{INTRODUCTION}

Since the 1960s, forest companies, federal and state public institutions and universities in Brazil have been applying genetic improvement in species Pinus taeda L. and it resulted in substantial yield increase (AGUIAR et al., 2011). Mobasa's (Modo Battistella Reflorestamento S.A.) genetic improvement program was launched in the 1970s and it was pioneer in producing improved $P$. taeda seeds in Brazil, with emphasis on individual selection for yield purposes.

Volumetric production of traits in Pinus plants recorded high genetic gain rates and it enabled producing forests with straighter stems, fewer bifurcations and fewer thick branches, which led to better industrial use of wood, mainly for furniture manufacturing (ASSIS; RESENDE, 2011).

Genetic improvement programs applied to perennial species require understanding the genetic control of traits of interest, at different progeny assessment stages, to enable defining the best genetic improvement and gain 
strategy based on genotype selection (FARIAS NETO et al., 2012). Time is a critical factor, since exploration processes involve long and costly cycles (BELTRAME et al., 2012).

Intra-population recurrent selection is the strategy most often adopted in breeding programs applied to Pinus species, although controlled intra-specific crossings are also common practice in some programs (ASSIS; RESENDE, 2011). It is necessary finding alternatives to reduce the time necessary to complete a breeding generation; thus, it is advantageous for breeding programs to select superior genotypes based on the first production years. Early selection is one of the aforementioned alternatives (MASSARO et al., 2010).

It is important checking genetic correlations between variables over time in order to measure early selection efficiency based on indirect gains to be observed in juvenile plants in comparison to those of adult plants. This short-term gain projection must be carefully evaluated for its implementation and effective gain at adult age. Such an evaluation is possible because variables such as diameter, height and volume are significantly correlated to each other at different ages, and it makes early genetic material selection feasible (MASSARO et al., 2010).

The present research assumes that there is genetic correlation among growth variables; thus, it is possible estimating the correlation between juvenile and adult ages in order to determine the best period for early selection processes. Thus, the aims of the current study were to estimate genetic parameters in juvenile (6) and adult (10 and 20 years old) plants, to check the genetic correlation between variables at different ages, and to determine whether it is possible performing efficient early selection in juvenile plants.

\section{MATERIALS AND METHODS}

\section{Experimental site and genetic material}

The experimental site is located in Rio Negrinho County, Santa Catarina State, Northern Plateau region. According to Köppen's classification, the climate in the region is classified as Cfb, humid subtropical with mild summer, no dry season and frequent severe frosts (ALVARES et al., 2013). Mean annual temperature ranges from $15.5^{\circ} \mathrm{C}$ to $17.0^{\circ} \mathrm{C}$. Mean temperature ranges from $20^{\circ} \mathrm{C}$ to $22^{\circ} \mathrm{C}$ in the hottest month (January) and from $12^{\circ} \mathrm{C}$ to $14^{\circ} \mathrm{C}$ in the coldest month (July) (BOGNOLA et al., 2008).

The progeny test has followed a randomized block design with 120 progenies, 5 repetitions and linear plots comprising 5 plants at $2.5 \mathrm{~m}$ x $2.5 \mathrm{~m}$ spacing. The adopted genetic material derived from Clonal Orchard (ramets); the test (seeds) was installed in 1997 and it comprised 19 specimens from Florida, 41 from Georgia, 27 from Louisiana and 28 from Zimbabwe, in addition to 5 commercial controls. Variables such as diameter at breast height $(\mathrm{DBH}, \mathrm{cm})$ and height $(\mathrm{m})$ were measured in all individuals at 6,10 and 20 years; these data were used to estimate the volume of trees with bark, based on the following expression:

$$
\text { Volume }_{c c}=\frac{\pi(D B H)^{2} x \text { Height }}{40000} \times s f
$$

Wherein:

Volume $_{c c}=$ volume of tree with bark in cubic meter;

$\mathrm{DBH}=$ diameter at breast height (1.30 $\mathrm{m}$ above soil $)$ in centimeters;

Height $=$ Total tree height in meters, and;

$\mathrm{sf}=$ tree shape factor.

\section{Genetic parameter estimates}

Genetic analyses of progeny tests were carried out in SELEGEN software - REML/BLUP®. Statistical model 1 was used to select individuals and parents in half-sib progenies in the herein adopted experimental design (RESENDE, 2016):

$$
y=X r+Z a+W p+e
$$

Wherein:

$y$ : data vector;

$r$ : repetition effects' vector (assumed to be fixed) added to the overall mean;

$a$ : individual additive genetic effects' vector (assumed to be random);

$p$ : plot effects' vector, it is the vector of errors or residuals (random),

$\mathrm{X}, \mathrm{Z}$ and $\mathrm{W}$ : incidence matrices for the aforementioned effects.

\section{Analysis of deviance}

Analysis of deviance (ANADEV) was carried out to test model's random effect significance, based on the maximum likelihood-ratio test (LRT), whose significance was assessed through Chi-square test with one degree of freedom. The LRT replaces the ANOVA and the F test (analysis of variance) in cases of models presenting unbalanced data (RESENDE, 2016). 


\section{Genetic correlations between growth and age variables}

Genetic correlations were performed for variables DBH, H and VOL in order to guide the breeding strategies, as well as the correlation among ages. Model 1 of the SELEGEN REML/BLUP software was used for analysis purposes. expression:

Genetic correlation analyses were applied to growth traits (DBH, H and VOL), based on the following

$$
r a(x, y)=\frac{\operatorname{CoV} a(x, y)}{\sigma a x \sigma a y}
$$

Wherein:

$r a(x y)$ : additive genetic correlation between traits $\mathrm{x}$ and $\mathrm{y}$;

COV: additive genetic covariance between traits $\mathrm{x}$ and $\mathrm{y}$;

$\sigma a x$ : additive genetic standard deviation for trait $\mathrm{x}$, and;

бay: additive genetic standard deviation for trait $\mathrm{y}$

\section{Seed orchards' formation}

Selection intensities were only applied to individuals with positive additive genetic value at all three ages, i.e., individuals that could represent genetic gain in comparison to the base population.

Decreasing selection intensities were applied for seed orchards' formation purposes. Six-year-old individuals were subjected to 7 selection intensities $(5 \%, 8 \%, 10 \%, 15 \%, 20 \%, 30 \%$ and 45\%), 10-year-old individuals were subjected to 5 selection intensities $(5 \%, 8 \%, 10 \%, 15 \%$ and 20\%), whereas 20-year-old individuals were subjected to 3 intensities $(5 \%, 8 \%$ and 10\%); with restriction of 5 individuals per family.

\section{Effective population size ( $\mathrm{Ne})$}

Effective population size was calculated based on the expression used for selection procedures in experimental allogamous monoecious populations comprising varying numbers of individuals selected per halfsib family, wherein $\mathrm{Nf}$ is the number of selected families and $\mathrm{Kf}$ is the mean number of individuals selected per family (RESENDE, 2015).

$$
N e=\frac{4 N f, K f}{K f+3} \text {, wherein: }
$$

$\mathrm{Ne}=$ Effective population size;

$N f=$ Number of selected families; and

$K f=$ Number of individuals selected per family.

\section{Genetic gain}

Genetic gain was calculated based on the following equation:

$$
\left.G_{\%}=\left(\overline{a_{s}}\right) / \bar{\mu}\right) \times 100 \text {, wherein: }
$$

$\overline{a_{s}}=$ Mean genetic value recorded for selected individuals and, $\mu=$ Mean value recorded in the test.

\section{RESULTS}

Based on results recorded for estimates of parameter 'diameter at breast height' (DBH) (Table1), additive genetic variance $\left(\sigma_{a}^{2}\right)$ recorded the lowest value $(2.75)$ at 6 years, whereas the highest value was recorded at 10 years and presented small decrease at 20 years. Variables such as Height $(\mathrm{H})$ and Volume (VOL) have also shown this behavior. Environmental variance between plots $\left(\sigma_{\text {plot }}^{2}\right)$ recorded the lowest value $(0.2918)$ at 10 years; environmental variance recorded at 6 years $(0.4165)$ was lower than the one recorded at 20 years $(0.4633)$. Variable 'DBH' recorded the largest variations within plots. Variable ' $\mathrm{H}$ ' recorded the lowest environmental variance at 10 years (0.2918), and VOL also presented the lowest estimate at 10 years $(0.003)$.

Individual heritability in the strict sense $\left(h_{a}^{2}\right)$ recorded the highest magnitude for all three variables at 10 years, whereas $\mathrm{H}$ recorded higher estimates at 6 years than at 20 years. VOL estimates were similar in all 3 investigated ages. Variable DBH at 10 years was $37 \%$ higher than that observed at 6 years. 
Table 1. Genetic parameter estimates calculated for variables DHB $(\mathrm{cm}), \mathrm{H}(\mathrm{m})$ and VOL $\left(\mathrm{m}^{3}\right)$ in progeny test applied to 6-, 10- and 20-year-old $P$. taeda specimens, Rio Negrinho County, Santa Catarina State.

Tabela 1. Estimativa de parâmetros genéticos da variável DAP $(\mathrm{cm}), \operatorname{ALT}(\mathrm{m})$ e VOL $\left(\mathrm{m}^{3}\right)$ em um teste de progênies de $P$. taeda aos seis, 10 e 20 anos, em Rio Negrinho, Estado de Santa Catarina.

\begin{tabular}{lccccccccc}
\hline & DBH6 & H6 & VOL6 & DBH 10 & H10 & VOL10 & DBH20 & H20 & VOL20 \\
\hline$\sigma^{2}{ }_{\mathrm{a}}$ & 2.7562 & 0.6405 & 0.0011 & 9.2688 & 0.9348 & 0.0068 & 6.0108 & 0.2109 & 0.0290 \\
$\sigma^{2}{ }_{\text {plot }}$ & 0.5228 & 0.4165 & 0.0007 & 0.5316 & 0.2918 & 0.0003 & 0.1989 & 0.4633 & 0.0015 \\
$\mathrm{~h}^{2}{ }_{\mathrm{a}}$ & 0.2929 & 0.3866 & 0.2097 & 0.4040 & 0.4157 & 0.3363 & 0.2120 & 0.0544 & 0.2301 \\
& $+/-0.06$ & $+/-0.07$ & $+/-0.05$ & $+/-0.07$ & $+/-0.07$ & $+/-0.06$ & $+/-0.05$ & $+/-0.03$ & $+/-0.06$ \\
$\mathrm{c}_{\text {plot }}^{2}$ & 0.0556 & 0.2514 & 0.1242 & 0.0232 & 0.1298 & 0.0135 & 0.0070 & 0.1196 & 0.0119 \\
$\mathrm{Ac}_{\text {prog }}$ & 0.7838 & 0.7474 & 0.6898 & 0.8473 & 0.8046 & 0.8272 & 0.7590 & 0.4341 & 0.7696 \\
$\mathrm{CV}_{\text {ig }} \%$ & 8.9129 & 6.9668 & 18.0020 & 13.5964 & 5.7798 & 25.4199 & 8.5683 & 1.5652 & 18.3108 \\
$\mathrm{CV}_{\mathrm{gp}} \%$ & 4.4565 & 3.4834 & 9.0010 & 6.7982 & 2.8899 & 12.7100 & 4.2842 & 0.7826 & 9.1554 \\
$\mathrm{CV}_{\mathrm{e}} \%$ & 7.8951 & 6.9229 & 21.1274 & 9.5268 & 4.7689 & 19.3056 & 8.2177 & 3.6315 & 16.9846 \\
$\mathrm{CV}_{\mathrm{r}}$ & 0.5645 & 0.5032 & 0.4260 & 0.7136 & 0.6060 & 0.6584 & 0.5213 & 0.2155 & 0.5390 \\
$\begin{array}{l}\text { Overall } \\
\text { mean }\end{array}$ & 18.6267 & 11.4880 & 0.1871 & 22.3918 & 16.7278 & 0.3238 & 28.6135 & 29.3373 & 0.9295 \\
\hline
\end{tabular}

Note: $\sigma_{\mathrm{a}}^{2}$ : additive genetic variance; $\sigma_{\text {plot }}^{2}$ environmental variance between plots; $\mathrm{h}_{\mathrm{a}}^{2}$ : individual heritability in the strict sense; $\mathrm{c}^{2}$ plot: coefficient of determination of plot effects; $\mathrm{h}^{2}{ }_{\mathrm{mp}}$ : mean progeny heritability; $\mathrm{Ac}_{\mathrm{prog}}$ : progeny selection accuracy; $\mathrm{CV}_{\mathrm{ig} \%}$ : individual additive genetic variation coefficient; $\mathrm{CV}_{\mathrm{gp} \%}$ : coefficient of genotypic variation between progenies; $\mathrm{CV}_{\mathrm{e} \%}$ : residual variation coefficient; $\mathrm{CV}_{\mathrm{r}}$ : relative coefficient of variation; $\mathrm{u}=$ overall mean of the experiment.

Determination coefficient recorded for DBH within the plot $\left(c_{\text {plot }}^{2}\right)$ ranged from 5.56\% at 6 years, to $2.32 \%$ at 10 years and to $0.07 \%$ at 20 years, after phenotypic model adjustment - this parameter is an experimental quality measure. The $c_{p l o t}^{2}$ value recorded for $\mathrm{H}$ at 6 years was 0.25 ; it decreased by $50 \%$ at 10 years $(0.13)$ and remained slightly lower than that value at 20 years. The $c_{p l o t}^{2}$ value recorded for volume presented its highest estimate at 10 years and the lowest one at 20 years.

Progeny selection accuracy $\left(\mathrm{Ac}_{\mathrm{prog}}\right)$ recorded for DBH at 6 years $(0.7838)$ presented its maximum value at 10 years $(0.8430)$ and the lowest value at 20 years $(0.7590)$. The highest $\mathrm{H}$ estimate was recorded at 10 years, whereas the lowest one was observed at 6 years. Both VOL and H recorded the highest estimate at 10 years and lowest one, at 6 years. This parameter accounts for the quality of predicted information.

Variable 'DBH' recorded the highest individual additive genetic variation coefficient $\left(\mathrm{CV}_{\mathrm{ig}} \%\right)$ at 10 years; estimates performed at 6 and 20 years recorded close values. The highest $\mathrm{H}$ estimates were observed at 6 years; they were followed by estimates recorded at 10 and 20 years, respectively. Variable 'VOL' has shown the same behavior as DBH - i.e., it recorded the highest estimate at 10 years. Variable 'VOL' recorded the highest coefficient of genotypic variation between progenies $\left(\mathrm{CV}_{\mathrm{gp} \%}\right)$ at all 3 investigated ages. The lowest residual variation coefficient $\left(\mathrm{CV}_{\mathrm{e}} \%\right)$ was recorded for $\mathrm{DBH}$ at all 3 ages. Relative variation coefficient $\left(\mathrm{CV}_{\mathrm{r}}\right)$ recorded the highest estimates for the 3 variables, at 10 years.

Genotypic effects' significance was evaluated through analysis of deviance (Table 2). Variables DBH, H and VOL recorded significant effects of progenies, at $1 \%$ probability level, at 6 and 10 years, whereas $\mathrm{H}$ was the only variable that did not record significant effects of progenies at 20 years. There was significant plot effect on all evaluated traits. This outcome has indicated differences in all traits within plots at 6 years, and in $\mathrm{H}$ at 10 and 20 years. 
Table 2. Analysis of deviance applied to DHB (cm), H (m) and VOL $\left(\mathrm{m}^{3}\right)$ in progeny test conducted with $P$. taeda specimens at 6,10 and 20 years.

Tabela 2. Análise de deviance para as variáveis DAP $(\mathrm{cm}), \operatorname{ALT}(\mathrm{m})$ e VOL $\left(\mathrm{m}^{3}\right)$ em teste de progênies de $P$. taeda aos seis, 10 e 20 anos de idade.

\begin{tabular}{|c|c|c|c|}
\hline \multirow{2}{*}{ Age (years) } & \multirow{2}{*}{ Variable } & \multicolumn{2}{|c|}{ LRT } \\
\hline & & Progenies & Plots \\
\hline \multirow{3}{*}{6} & $\mathrm{DBH}$ & $33.58 * *$ & $10.31 * *$ \\
\hline & $\mathrm{H}$ & $27.07 * *$ & $193.79 * *$ \\
\hline & VOL & $14.71 * *$ & $47.41 * *$ \\
\hline \multirow{3}{*}{10} & $\mathrm{DBH}$ & $68.23^{* *}$ & $2.18^{\mathrm{ns}}$ \\
\hline & $\mathrm{H}$ & $45.22 * *$ & $59.57 * *$ \\
\hline & VOL & $58.02 * *$ & $0.71^{\mathrm{ns}}$ \\
\hline \multirow{3}{*}{20} & $\mathrm{DBH}$ & $28.58 * *$ & $0.11^{\mathrm{ns}}$ \\
\hline & $\mathrm{H}$ & $1.24^{\mathrm{ns}}$ & $29.06 * *$ \\
\hline & VOL & $24.48 * *$ & $0.26^{\mathrm{ns}}$ \\
\hline
\end{tabular}

Note: LRT: Likelihood-ratio test; ** Significant at $1 \%$ based on Chi-square test, with 1 degree of freedom; $*$ Significant at $5 \%$ based on Chisquare test, with 1 degree of freedom; and ${ }^{\text {ns }}$ non-significant.

Based on additive genetic correlations (Table 3), the correlation between DBH and VOL was high at all analyzed ages; the highest correlation ( 0.98$)$ between these variables was observed at 10 years. Genetic correlations between $\mathrm{DBH}$ and $\mathrm{H}$ presented lower values; the lowest correlation between these variables was observed at 20 years $(0.54)$ and all values presented moderate correlation. On the other hand, H and VOL recorded the highest correlation at 10 years $(0.76)$.

Table 3. Genetic correlation among variables 'DHB' $(\mathrm{cm})$, 'H' $(\mathrm{m})$ and 'VOL' $\left(\mathrm{m}^{3}\right)$ in progeny test conducted with $P$. taeda specimens at different ages, in Rio Negrinho County, Santa Catarina State.

Tabela 3. Correlações genéticas entre as variáveis DAP $(\mathrm{cm})$, ALT $(\mathrm{m})$ e VOL $\left(\mathrm{m}^{3}\right)$ de um teste de progênies de P. taeda, em diferentes idades localizado em Rio Negrinho, Estado de Santa Catarina.

\begin{tabular}{lccc}
\hline & \multicolumn{3}{c}{ Age (years) } \\
\cline { 2 - 4 } Variables & Six & Ten & Twenty \\
\hline DBH X H & $0.61^{* *}$ & $0.73^{* *}$ & $0.54^{*}$ \\
DBH X VOL & $0.92^{* *}$ & $0.98^{* *}$ & $0.91^{* *}$ \\
H X VOL & $0.75^{* *}$ & $0.76^{* *}$ & $0.68^{* *}$ \\
\hline
\end{tabular}

Note: ** Significant at $1 \%$ based on T test, with 1 degree of freedom; * Significant at $5 \%$ based on $\mathrm{T}$ test, with 1 degree of freedom; and ${ }^{\mathrm{ns}}$ non-significant.

Based on Table 4, 20-year-old specimens have shown moderate genetic correlation to 6- and 10-year-old specimens. There was high genetic correlation between 10- (juvenile) and 20-year-old (adult) specimens, as well as between 10- and 6-year-old specimens; however, lower genetic correlation value $(0.60)$ was observed between 10- and 20-year-old specimens (0.64).

Table 4. Genetic correlation recorded for DHB between ages, in progeny test applied to P. taeda specimens, Rio Negrinho County, Santa Catarina State.

Tabela 4. Correlação genética entre idades para a variável DAP em progênies de $P$. taeda, em teste de progênies localizados no município de Rio Negrinho, Estado de Santa Catarina.

\begin{tabular}{lccc}
\hline & DBH6 & DBH10 & DBH20 \\
\hline DBH6 & 1 & & \\
DBH10 & $0.60^{*}$ & 1 & \\
DBH20 & $0.39^{\mathrm{ns}}$ & $0.64^{*}$ & 1 \\
\hline
\end{tabular}

Note: $* *$ Significant at $1 \%$ based on $\mathrm{T}$ test, with 1 degree of freedom; * Significant $5 \%$ based on $\mathrm{T}$ test, with 1 degree of freedom; and ${ }^{\mathrm{ns}}$ nonsignificant. 
Simulations presented in Table 5 were performed to check gains obtained at different ages and selection intensities. The higher the selection intensity, the smaller the effective population size associated with the genetic representativeness of the population. Effective population size should be taken into consideration at the time to set the minimum selection value to avoid genetic erosion and selective population bottleneck. Based on genetic gains in time (GS\%/t) recorded for the highest selection intensities, there was genetic gain by $1.82 \% / y e a r$ at 6 years; by $1.83 \%$ /year, at 10 years; and by $0.58 \%$ /year, at 20 years. Juvenile specimens recorded the highest genetic gains per unit of time; however, one should check economic factors associated with the forestry activity, and with its financial return to foresters, in order to identify the best time to select genetic materials.

Table 5. Genetic gains and effective population size in progeny test applied to Pinus taeda specimens, at different selection intensities and at 3 different ages, in order to form clonal seed orchards using diameter at breast height (DHB).

Tabela 5. Ganhos genéticos e tamanho efetivo populacional com diferentes intensidades de seleção para três idades de um teste de progênies de Pinus taeda no Estado de Santa Catarina, município de Rio Negrinho, para formação de pomares clonais de sementes via diâmetro a altura do peito (DAP).

\begin{tabular}{|c|c|c|c|c|c|c|c|c|}
\hline \multirow[b]{2}{*}{ Age } & & \multicolumn{7}{|c|}{ Selection Intensity } \\
\hline & & $5 \%$ & $8 \%$ & $10 \%$ & $15 \%$ & $20 \%$ & $30 \%$ & $45 \%$ \\
\hline \multirow{4}{*}{ 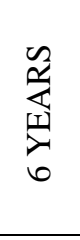 } & $\mathrm{NF}$ & 65 & 104 & 130 & 195 & 260 & 390 & 525 \\
\hline & $\mathrm{NE}$ & 43 & 62 & 70 & 90 & 108 & 144 & 172 \\
\hline & $\mu$ Pop. Sel. & 20.63 & 20.53 & 20.46 & 20.31 & 20.2 & 20.04 & 19.9 \\
\hline & $\mathrm{G} \%$ & 10.97 & 10.23 & 9.85 & 9.05 & 8.47 & 7.58 & 6.86 \\
\hline \multirow{4}{*}{ 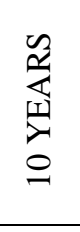 } & NF & 73 & 116 & 145 & 218 & 290 & & \\
\hline & $\mathrm{NE}$ & 50 & 68 & 79 & 103 & 126 & & \\
\hline & $\mu$ Pop. Sel. & 26.5 & 26.22 & 26.08 & 25.78 & 25.56 & & \\
\hline & $\mathrm{G} \%$ & 18.35 & 17.1 & 16.47 & 15.14 & 14.13 & & \\
\hline \multirow{4}{*}{ 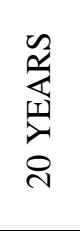 } & NF & 55 & 87 & 109 & & & & \\
\hline & $\mathrm{NE}$ & 20 & 34 & 43 & & & & \\
\hline & $\mu$ Pop. Sel. & 31.95 & 31.66 & 31.5 & & & & \\
\hline & $\mathrm{G} \%$ & 11.68 & 10.65 & 10.1 & & & & \\
\hline
\end{tabular}

Note: NF: number of individuals; NE: effective population size; $\mu$ Pop. Sel.: mean of selected population; G\%: genetic gain (\%).

\section{DISCUSSION}

Individual heritability in the strict sense $\left(h_{a}^{2}\right)$ explains to what extent the genotype is expressed in the phenotype. According to Resende (2015), there are three $h_{a}^{2}$ magnitude classes, namely: low, which corresponds to variation $0.01 \leq h_{a}^{2} \leq 0,15$; average or moderate, which corresponds to variation $0.15<h_{a}^{2}<0.50$; and high, which corresponds to condition $h_{a}^{2} \geq 0.50$. Moderate individual heritability was observed at 6,10 and 20 years; the highest value was observed at 10 years (0.40). Ishibashi et al. (2017) recorded individual heritability values ranging from 0.24 to 0.43 in a 9-year-old settlement, in Rio Negrinho County (SC). Coutinho et al. (2017) conducted a study aimed at investigating early selection in 8- and 15-year-old test progenies grown in Paraná State (Campo do Tenente, Sengés and Jaguariaíva counties) and found heritability values ranging from 0.08 to 0.26 . Throughout the test development, values recorded for this parameter have decreased in the last evaluation period, likely due to effects of competition among plants. Selecting individuals when they present maximum heritability value can be a strategy to maximize population genetic gains in selection processes, as long as the selection age is highly correlated to the harvest age.

According to Coutinho et al. (2017), tree-height heritability ranged from 0.18 to 0.37 . With respect to the current study, $h_{a}^{2}$ (Table 5) presented estimate of 0.41 at 10 years; it was the best value in comparison those recorded at $6(0.38)$ and 20 years (0.05). According to Resende (2015), heritability over time presented moderateto-low intensity. Martinez et al. (2012) have shown variation from 0.09 to 0.53 in progeny test applied to 6-yearold $P$. taeda specimens.

The higher the $\mathrm{CV}_{\mathrm{ig}} \%$, the higher the chances of finding superior individuals or individuals recording the highest $\mathrm{CV}_{\mathrm{ig}} \%$ value (Miranda et al., 2015). Thus, variable 'height' presented low potential for individual selection 
and for selection between progenies $\left(\mathrm{V}_{\mathrm{gp}}\right)$ in the current test. The aforementioned $\mathrm{CV}_{\mathrm{ig}} \%$ pattern observed for this variable was also observed for $\mathrm{CV}_{\mathrm{e}} \%$ and $\mathrm{CV}_{\mathrm{r}}$; experimental variation coefficient was low at all ages.

Deviance analysis data have shown variability in these traits between progenies, and it enabled successful selection outcomes. The non-significant effect recorded for $\mathrm{H}$ at 20 years may be associated with lack of competition for this trait. According to Stuion and Resende (2010), selection can be performed at different levels, namely: between populations, within populations, and simultaneously between and within populations, by combining genetic values of different populations and of individuals within populations. The best strategy depends on the value recorded for variables of interest in each population. Based on genetic parameters estimated for the three evaluated growth variables (diameter at breast height, height and volume), and based on the analysis of deviance, height did not show variability in the investigated progenies; thus, genetic selection based on this trait was unfeasible. On the other hand, DBH and VOL have shown potential to be used for the genetic selection of individuals.

Genetic correlations mainly result from pleiotropism and from imbalanced genetic linkage (CRUZ, 2012). Pleiotropism is the phenomenon through which a given gene simultaneously affects two, or more, traits; thus, if this phenomenon takes place, alleles segregate and there is simultaneous variation in the involved traits. Genetic linkage imbalance is transient cause of genetic correlation and it may be changed in advanced generations by breaking gene sets through crossovers (CRUZ, 2012). According to Resende (2015), correlation coefficients can be classified by taking into consideration their magnitude: magnitudes ranging from 0.0 to 0.33 are considered low, those ranging from 0.34 to 0.66 are considered moderate, and the ones ranging from 0.67 to 1.0 are considered high. It is worth emphasizing that the highest correlations recorded between variables and between their combinations were observed at 10 years; there was high correlation between variables (RESENDE, 2015). High correlations between growth traits were also reported by Paludzyszyn Filho et al. (2002) and by Martinez et al. (2012) in species P. taeda. According to Xiang et al. (2003), DBH and volume in species $P$. Taeda presented high genetic correlation throughout 8 years of study (Southeastern USA) - values ranged from 0.8 to 0.9 .

The selection of genetically superior trees at different ages is an important aspect to be taken into consideration in genetic improvement programs. Early selection is an indirect form of selection, based on which traits observed at ages previous to the rotation age are used as predictors of economically important traits at rotation age (FONSECA et al., 2010).

The adoption of early selection processes is mainly aimed at shortening breeding cycles by decreasing the time required for evaluation and selection procedures, in order to maximize genetic gains per unit of time (year). Traits evaluated at previous ages to the optimal rotation age of the desired species are used as predictors of economically important traits.

It is important determining the genetic correlation between juvenile and adult $P$. taeda specimens to enable genetic selection within a shorter period-of-time (in years). If one takes into consideration $P$. Taeda's rotation cycle (commercial cycles range from 14 to 22 years), it is necessary shortening the time required for evaluation and selection procedures in order to maximize genetic gains per unit of time (year) in genetic improvement programs applied to long-cycle species.

Correlations observed at early and late ages have suggested that different physiological mechanisms play key role at different development stages, a fact that can be attributed to different genes and expression mechanisms. However, the expression of these genes stabilizes over the years, as evidenced by high correlation between halfand full-rotation ages (Dias et al., 2016). There was decreasing correlation between ages, regardless of the age indicated for harvest $(6,10$ or 20 years); the lowest values were recorded for selections held at juvenile ages.

Dias et al. (2016) worked with three different ages (1, 3 and 4 years) of clonal tests of $P$. Taeda propagated via somatic embryogenesis in Paraná and Santa Catarina states. Their results have shown that the lowest correlations observed among growth variables (DBH, H and VOL) were recorded between the youngest and the oldest evaluation ages. The current study has observed similar outcome in the evaluation conducted throughout the rotation cycle. This behavior is likely a pattern, according to which, the youngest age presents the lowest correlations to the final evaluations.

Results have evidenced significant physiological changes taking place in conifers' transition from the juvenile to the mature stage; these changes lead to remarkable differences in growth rates and in other properties (RESENDE JR et al.; 2012). According to the progeny test evaluated in the present study, 10 years is ideal age for early selection focused on predicting the best individuals at the end of the rotation cycle.

Gwaze et al. (2001) have also observed efficient early selection for genetic parameters such as diameter at breast height, height and wood density, in comparison to that of late selection. They analyzed 4 genetic tests of P. taeda grown in Arkansas, which were evaluated at 5, 10, 15, 20 and 25 years. The aforementioned authors concluded that the selection performed at young ages was efficient, as well as that diameter at breast height presented genetic correlation higher than 0.89 at ages ranging from 10 to 20 years; this outcome enabled making genetic recommendations with excellent accuracy 10 years in advance. The best selection age for Pinus abies L.

FLORESTA, Curitiba, PR, v. 51, n. 4, p. 937-945, out/dez 2021.

Flores Jr., P. C. et.al.

ISSN eletrônico 1982-4688

DOI: $10.5380 /$ rf.v51 i4. 74441 
is 17 years; however, it can be shortened down to 13 years and still be used to predict the best individuals based on high data accuracy (ISIK et al., 2010). It is important highlighting that specific final cut cycles within genetic improvement programs applied to species $P$. taeda take place at approximately 14 and 20 years. Because they are long cycles, the advancement of genetic improvement programs based on early selection should take into account the genetic gains and the best age to maximize yield and, consequently, to maximize the financial return to foresters.

Among strategies focused on enabling yield gain, selection intensity was the parameter used in the selection process to ensure genetic variability and new selection cycles within the population. Different strategies can be used to form orchards capable of meeting the demands of foresters and orchards focused on seed trading; among them, one finds restricting the number of individuals per family to guarantee genetic bases capable of supporting successive selective cycles. According to Dvorak (2012), effective population size comprising 30 individuals is enough to preserve most alleles taking place in Pinus populations at frequency of 5\%.

The higher genetic gain observed at 6 years was associated with higher selection intensity and with smaller effective population size. Genetic gain variation (higher / lower intensity) reached 62.5\% and presented effective population size of wide magnitude. Martinez et al. (2012) and Dias et al. (2016) have selected genetic materials at close ages, but they did not evaluate population development throughout the rotation cycle. Selection at juvenile age is feasible and represents gains in comparison to the test. However, it is important emphasizing that, in comparison to the species' rotation cycle, this selection was not effective because individuals selected at early ages did not represent the best individuals at the end of the cycle.

Maximum genetic correlation between individuals was $67.21 \%$, even at high selection intensities $(30 \%$ and $45 \%$ ); thus, many individuals were necessary to achieve genetic gain of $7.58 \%$ in the selected population. According to Giordani et al. (2012), a more solid approach to genetic gain based on selection processes refers to the proportion of individuals or families selected based on a certain trait, at a certain year; such a proportion will remain among individuals selected based on the same trait, or on another one, at subsequent years.

\section{CONCLUSION}

- Genetic parameters estimated for all three investigated ages (6,10 and 20 years) have shown that the age of 10 years enabled the best estimates, with high accuracy, for the three variables, which presented high genetic correlation.

- Correlations between juvenile and adult age were higher at 10 years.

- Early selection carried out in the mid-cycle (10 years) presented selective progeny efficiency in predicting gains in comparison to that of the end of the rotation cycle.

\section{ACKNOWLEDGMENT}

The authors are grateful to the National Council for Scientific and Technological Development (CNPq Conselho Nacional de Desenvolvimento Científico e Tecnológico), to the Coordination for the Improvement of Higher Education Personnel (CAPES - Coordenação de Aperfeiçoamento de Pessoal de Nível Superior) and to the company Valor Florestal (Forest Value) for the financial and logistical support provided for the development of the current study.

\section{REFERENCES}

AGUIAR, A. V.; SOUSA, V. A., FRITZSONS, E.; PINTO JUNIOR, J. E. Programa de melhoramento de Pinus da Embrapa Florestas. Documento 233. Embrapa Florestas, Colombo, PR, 2011. 83 p.

ALVARES, CA; STAPE, JL; SENTELHAS, PC; de MORAES, G; LEONARDO, J; SPAROVEK, G Köppen's climate classification map for Brazil, Meteorologische Zeitschrift, v. 22, n. 6, p. 711-728, 2013.

ASSIS, T. F.; RESENDE, M. D. V. Genetic improvement of forest tree species. Crop Breeding and Applied Biotechnology, S1, p. 44 -49, 2011.

BELTRAME, R.; BISOGNIN, D. A.; MATTOS, B. D.; CARGNELUTTI FILHO, A.; HASELEIN, C. R.; GATTO, D. A.; SANTOS; G. A. Desempenho silvicultural e seleção precoce de clones de híbridos de eucalipto. Pesquisa Agropecuária Brasileira, Brasília, v.47, n.6, p.791-796, 2012.

BOGNOLA, I.A.; RIBEIRO JUNIOR, P.J.; SILVA, E.A.A.; LINGNAU, C.; HIGA, A.R. Modelagem uni e bivariada da variabilidade espacial de rendimento de Pinus taeda L. Floresta, Curitiba, v. 38, n. 2, p. 373-385, 2008 . 
COUTINHO, R. T.; BESPALHOK FILHO, J. C.; FRITSCHE NETO, R.; FRIZZO, C. Viabilidade da seleção precoce de Pinus taeda L. em diâmetro a altura do peito em programa de melhoramento genético. Scientia Forestalis, Piracicaba, v. 45, n. 113, p. 205-219, 2017.

CRUZ, C. D.; REGAZZI, A. J.; CARNEIRO, P. C. S. Modelos biométricos aplicados ao melhoramento genético. v. 1, 4. Ed.Viçosa: UFV, 2012. 514 p.

DIAS, P. C.; XAVIER, A.; RESENDE, M. D. V.; BIERNASKI, F.; ESTOPA, R. A.; PIRES, I. E. Juvenile-mature genetic correlations in Pinus taeda clones propagated via somatic embryogenesis. Revista Árvore, Viçosa, v.40, n.2, p.255-267, 2016.

DVORAK, W. S. The strategic importance of applied tree conservation programs to the forest industry in South Africa. Southern Forests: a Journal of Forest Science, v. 74, n. 1, p. 1-6, 2012.

FARIAS NETO, J. T.; OLIVEIRA, M. S. P.; RESENDE, M. D. V.; RODRIGUES, J. C. Parâmetros genéticos e ganhos com seleção de progênies de Euterpe oleracea na fase juvenil. Cerne, Lavras, v. 18, n. 3, p. 515 -524, 2012.

FONSECA, S. M.; RESENDE, M. D. V.; ALFENAS, A. C.; GUIMAEÃES, L. M. S.; ASSIS, T. F.; GRATTAPAGLIA, D. Manual prático de melhoramento genético do eucalipto. Viçosa: UFV, 2010, p. 200.

GIORDANI, S. C. O.; FERNANDES, J. S. C.; TITON, M.; SANTANA, R. C. Parâmetros genéticos para caracteres de crescimento em pequizeiro em estádio precoce. Revista Ciência Agronômica, Fortaleza, v. 43, n. 1, p. 146-153, 2012.

GWAZE, D. P.; BRIDGWATER, F. E.; BYRAM, T. D.; LOWE, W. J. Genetic Parameter estimates for growth and wood density in loblolly pine (Pinus taeda L.). Forest Genetics, v. 8, n.1, p.47-55, 2001.

ISIK, K.; KLEINSCHMIT, J.; STEINER, W. Age-Age Correlations and Early Selection for Height in a Clonal Genetic Test of Norway Spruce. Forest Science, v. 56, n. 2, p. 212 -221, 2010.

ISHIBASHI, V.; MARTINEZ, D.T.; HIGA, A.R. Phenotypic models of competition for Pinus taeda L. genetic parameters estimation. Cerne, Lavras, v.23, n.3, p. 349-358, 2017.

MARTINEZ, D. T.; RESENDE, M. D. V.; COSTA, R. B.; HIGA, A. R.; SANTOS, G. A.; FIER, I. S. N. Estudo da interação genótipo x ambiente em progênies de Pinus taeda por meio da análise de parâmetros genéticos, Floresta, Curitiba, v. 42, n. 3, p. $539-552,2012$.

MASSARO, R. A. M.; BONINE, C. A. V.; SCARPITANI, E. A.; DE PAULA, R. C. Viabilidade de aplicação da seleção precoce em testes clonais de Eucalyptus spp. Ciência Florestal, Santa Maria, v.20, p.597-609, 2010.

MIRANDA, A. C.; MORAES, M. L. T.; SILVA, P. H. M.; SEBBEN, A. M. Ganhos genéticos na seleção pelo método do índice multi-efeitos em progênies polinização livre de Eucalyptus grandis Hill ex Maiden. Scientia Forestalis, Piracicaba, v. 43, n. 105, p. 203-209, 2015.

PALUDZYSZYN FILHO, E.; SHIMOYAMA, V.R.S. Seleção Precoce para Incremento Simultâneo do Crescimento e da Qualidade da Madeira em Pinus taeda L. Boletim da Pesquisa Florestal, Colombo, n.46, p. $31-46,2003$.

REIS, R. L.; MUNIZ, J. A.; FONSECA E SILVA, F.; AQUINO, L. H. Estimativas de variância genética aditiva em populações selecionadas e não-selecionadas via simulação Monte Carlo utilizando o software R. Ciência e Agrotecnologia, Lavras, v. 33, n. 1, p. 285-291, 2009.

RESENDE JR, M. F. R.; MUNÕZ, P.; ACOSTA, J. J.; PETER, G. F.; DAVIS, J. M.; GRATTAPAGLIA, D.; RESENDE, M. D. V. Accelerating the domestication of trees using genomic selection: accuracy of prediction models across ages and environments. New Phytologist, v. 193, p. 617-624, 2012.

RESENDE, M. D. V. Genética quantitativa e de populações. Viçosa, MG: Suprema. 463 p. 2015.

RESENDE, M. D. V. Software Selegen-REML/BLUP: a useful tool for plant breeding. Crop Breeding and Applied Biotechnology, .16, n. 4, p. 330-339, 2016.

STURION, J. F.; RESENDE, M.D.V. Avaliação genética e análise de deviance em um teste desbalanceado de procedência e progênie de Ilex paraguariensis. Pesquisa Florestal Brasileira, Colombo, v. 30, n. 62, p. 157 $160,2010$.

XIANG, B.; LI, B.; ISIK, F. Time Trend of Genetic Parameters in Growth Traits of Pinus taeda L. Silvae Genetica, v. 52, p. 114-121, 2003. 